\title{
Animals in the administrative zoo: organizational change and agency autonomy in Germany
}

\section{Tobias Bach}

University of Hannover, Department of Political Science,

Germany

\section{Werner Jann}

University of Potsdam, Faculty of Economics and Social Sciences,

Germany

\begin{abstract}
Although Germany does not figure among the 'forerunners' of managerial reforms of the public sector, it has a long tradition of agencies and non-departmental bodies at the federal level. Over time, the federal administration has developed into a highly differentiated 'administrative zoo' with a large number of species, questioning the image of a well-ordered German bureaucracy. The article addresses organizational changes among non-ministerial agencies during the past 20 years and ministry-agency relations, drawing on data from a comprehensive survey of the federal administration. The structural changes we observe are neither comprehensive nor planned; they are much more evolutionary than revolutionary, driven by sectoral policies and not by any overall agency policy, supported more by regulatory than by managerial reforms, and most of the changes are horizontal mergers or successions of existing organizations, while we find almost no evidence for hiving-off from ministries to agencies. At the same time, federal agencies report a lot of bureaucratic discretion, whereas they perceive substantial levels of 'red tape' due to administrative regulations. We also find that traditional, hierarchical modes of ministerial oversight are still dominating; only few agencies have performance agreements with measurable goals.
\end{abstract}

\section{Points for practitioners}

The article will be of interest to practitioners concerned about the nature and direction of organizational change within government, especially about processes of horizontal and vertical differentiation and steering. It demonstrates that even in a highly developed and classical bureaucratic administrative system such as Germany there is and has for a

\section{Corresponding author:}

Tobias Bach, Leibniz Universität Hannover, Institut für Politische Wissenschaft, Schneiderberg 50 , 30167 Hannover, Germany

Email: bach@ipw.uni-hannover.de 
long time been a large variety of governmental agencies that enjoy a considerable amount of autonomy. At the same time there is continuous change and adaptation to new circumstances, even though all this has very little to do with international modernization trends such as New Public Management or comprehensive agencification.

\section{Keywords}

administrative organization and structures, central administration, control, modernization, public sector reform, regulation

\section{Introduction}

The creation of executive agencies across various functions of government and reforms of already existing agencies has been observed in many OECD countries during roughly the past 20 years (Greve et al., 1999; Jann et al., 2008; Jann and Reichard, 2003; OECD, 2002; Pollitt and Bouckaert, 2004; Pollitt et al., 2001). ${ }^{1}$ Yet, this general picture of a seemingly uniform trend towards the 'agencification' of public bureaucracies is highly contingent and characterized by substantial variation of agencies and other public organizations both between and within countries (Döhler, 2007a; Gains, 2004; Greve et al., 1999; Pollitt et al., 2004).

Germany is rarely mentioned in the at times overflowing political and academic debate about agencification. The federal government is usually considered as a reform laggard or 'maintainer' in terms of public management reform (Pollitt and Bouckaert, 2004) which pursues most administrative reforms in a pragmatic and incremental way' (Schröter, 2007: 267). The federal administration with its numerous agencies and public bodies has not been subject to dramatic structural changes and may appear unspectacular and perhaps boring to external observers. Yet the internationally comparative analysis of agencies and agencification should also address and explain cases without major structural reforms in order to increase variation of the phenomenon under study and to understand patterns of incremental change and emergent reform strategies.

In this article, we address patterns of organizational change and ministryagency relations at the federal level of government in Germany, mainly using data from a comprehensive survey of federal agencies carried out by one of the authors in 2008. The analysis focuses roughly on the past 20 years; the period in which agencies have 'become a popular vehicle for executing a wide range of functions in a large number of countries' (Pollitt et al., 2001: 272).

We will look specifically at structural and procedural agencification. By structural agencification we mean changes in the formal organization of public tasks, e.g. creating new agencies, either by hiving-off tasks and personnel from existing ministerial departments or by splitting or merging existing agencies. Structural disaggregation or the creation of single-purpose organizations (or both at the same time) have been identified as a central element of the ideal-type 
modern agency (Pollitt et al., 2004; Talbot, 2004). However, in order to fully grasp the dynamics of structural changes, we also take into account developments towards a more centralized bureaucracy (e.g. reintegration of agencies into ministerial departments) and multi-task agencies.

By procedural agencification we mean a transfer of authority from ministries to agencies, which can be done by changing the internal or the external governance of agencies (or both). The internal dimension of procedural agencification relates to changing the rules and responsibilities for personnel, budgeting and organizational matters, thus granting agencies more (or less) managerial autonomy (Verhoest et al., 2004). In addition, this dimension includes bureaucratic discretion regarding the core tasks of the agency, or the degree to which agencies decide independently on various aspects of policy implementation (Bach, 2010; Lægreid et al., 2006; Verhoest et al., 2004). Yet procedural agencification also includes shifts in the relationship between ministries and agencies, for example by introducing contractual or other performance-oriented techniques and new forms of reporting which replace or supplement traditional instruments of hierarchical control (Jann and Reichard, 2003). In addition to structural disaggregation, Pollitt et al. (2004) and Talbot (2004) identify de-regulation and performance contracting as defining characteristics of an ideal-type modern agency, which correspond to the internal and external dimensions of procedural agencification in this article.

Furthermore, we analyse the motives for organizational change. Clearly, the reasons and motives for creating or reforming agencies are manifold, and we cannot do justice to all of them here (see Pollitt et al., 2004: 19-20, for an overview of 'noble' and 'less noble' motives). We look at dominant narratives and argue that agencification is driven by two separate reform discourses. The first one stresses the well-known elements of the New Public Management (NPM) reform agenda, such as separating policy and implementation, contract steering, stronger task orientation and more effectiveness and efficiency (OECD, 2002; Pollitt et al., 2001). The second discourse emphasizes the gradual development of a regulatory state, stressing the necessity of reliability and long-term credible commitment in government regulation, the inevitability of more professional specialization and therefore, at least to some degree, independence from direct political intervention in regulatory decisions (Christensen and Lægreid, 2007; Döhler, 2006).

In the following section, we address Germany's politico-administrative context and take stock of the various types of agencies and public organizations in the federal administration, followed by an overview of recent administrative reform policies. Then, we present our empirical data and methodological approach. In the following section, drawing on both survey and qualitative data, we analyse patterns of structural agencification in terms of vertical and horizontal (de)specialization and then discuss our empirical findings in the light of competing explanations of organizational change. After that we take a closer look at patterns of procedural agencification, mainly drawing on survey data regarding agency autonomy and 
vertical interaction between ministries and agencies. Finally, we discuss our findings and draw conclusions.

\section{The politico-administrative context}

The history and structure of administrations, as well as dominant norms, values, and patterns of politico-administrative behaviour are important factors for administrative reform and change (Christensen and Lægreid, 2001; Pollitt and Bouckaert, 2004). It is therefore necessary to start with a brief overview of the politico-administrative context of the German federal bureaucracy in order to understand possible changes.

\section{A long tradition of small ministries and many 'animals'}

Germany has a long tradition of public agencies and authorities outside core ministerial departments at the federal level of government (Dittmann, 1983; Döhler, 2007a; Welz, 1988). The first non-ministerial agency was founded shortly after the foundation of the German Empire in the 1870s, and the establishment of the authoritarian welfare state under Bismarck usually took the form of special agencies under public law. The increase in tasks and the functional specialization of the central (federal) bureaucracy continued after the creation of the Weimar Republic in 1918. In this period, central government took over functions from the states, new tasks were emerging, and the scale of existing functions was increasing in an 'almost explosive' way (Brecht and Glaser, 1940: 14). The Nazi dictatorship (1933-45) abolished the federal system of government and incorporated the state administrations into a unitary bureaucracy (Dittmann, 1983), but the new constitution of 1949 again created a federal system and explicitly delegated the implementation of (most) federal legislation to the states (Länder). At the same time it also provided for the creation of a distinct federal administration, which largely followed the traditions of the Weimar Republic in terms of its basic structure and organizational types.

According to this division of functions between levels of government, the states implement most federal policies, whereas the federation has mainly legislative functions, resulting in a relatively low relevance and visibility of federal agencies. For example, the building and maintenance of federal motorways, the wellknown Bundesautobahnen, is not a federal task, but is delegated to the Länder. ${ }^{2}$

The organizational consequence of this 'executive federalism' is that federal ministries are rather small, do not operate their own regional or local field offices and have few operative tasks. The only exceptions are the Ministry of Defence (civilian administration of the military), Finance (for customs and a joint tax administration with the states), Interior (for the border police), Transport (for inland waterways), and Foreign Affairs (embassies). In addition to these decentralized agencies, the federal administration also consists of a considerable number 
of central agencies with nation-wide responsibilities (although some of them also have decentralized offices).

The total number of central agencies grew at high speed in the 1950s, followed by a period of moderate, but constant growth until the beginning of the 1990s and a weak decline until 2006 (Adam et al., 2008). In 2008, there were about 85 central agencies within the direct administration and about 20 Intermediate Federal Authorities (Bundesmittelbehörden), i.e. decentralized agencies operating at the regional level (see Table 1). These figures suggest a long-term development of increasing relevance of federal agencies in policy implementation (Döhler, 2007a). In addition, they also raise the question why the number of central agencies has recently been declining, which will be addressed below.

Yet the above-mentioned agencies are only part of the story. In contrast to the image of a well-ordered, typically Weberian public bureaucracy, the German federal administration has developed into a highly diverse 'administrative zoo' with various organizational species and sub-species. ${ }^{3}$ In general, we distinguish between four categories of public sector organizations at the federal level (see Table 1): direct administration, indirect administration, private law administration, and charged administration (Becker, 1978; Döhler, 2007a; Loeser, 1994; PRVR, 1975; Schuppert, 1981).

The direct administration is the 'core bureaucracy' and includes the federal ministries and a large number of disaggregated organizations staffed with public employees and financed via the federal budget. Most central agencies are so-called Higher Federal Authorities (Bundesoberbehörden) which can be created by simple legislation (i.e. without the consent of the states). They typically perform sovereign state functions (hoheitliche Aufgaben) such as utility and drug regulation, cartel law, immigration, or statistics. Federal Institutions (nichtrechtsfähige Bundesanstalten) mostly have advisory or service delivery functions (e.g. agricultural research, health promotion), and Federal Commissioners (Bundesbeauftragte) typically perform watchdog functions (e.g. data protection).

In contrast, organizations belonging to the indirect administration are more remote from political control and have a legal personality distinct from the state (which among other things implies that they have their own budget). Also, the organizations in this category may be granted extended autonomy in terms of financial and personnel management compared to the core bureaucracy (Döhler, 2007b). Here we can distinguish three different legal types: (1) The large majority of indirect organizations are statutory bodies (Körperschaften), most of them running the social insurance system which dates back to the late nineteenth century. Thus, unlike countries such as the United Kingdom or the Netherlands (Caulfield, 2004), the ministries never had operational responsibility for social security and employment policies. In line with the German system of societal 'self-governance' (Selbstverwaltung), the statutory bodies' members (e.g. employers and employees in the case of the pension fund) are represented on governing and managing boards. The involvement of societal actors in the governing of these bodies is the defining characteristic of this legal type. (2) The Institutions of Public Law 


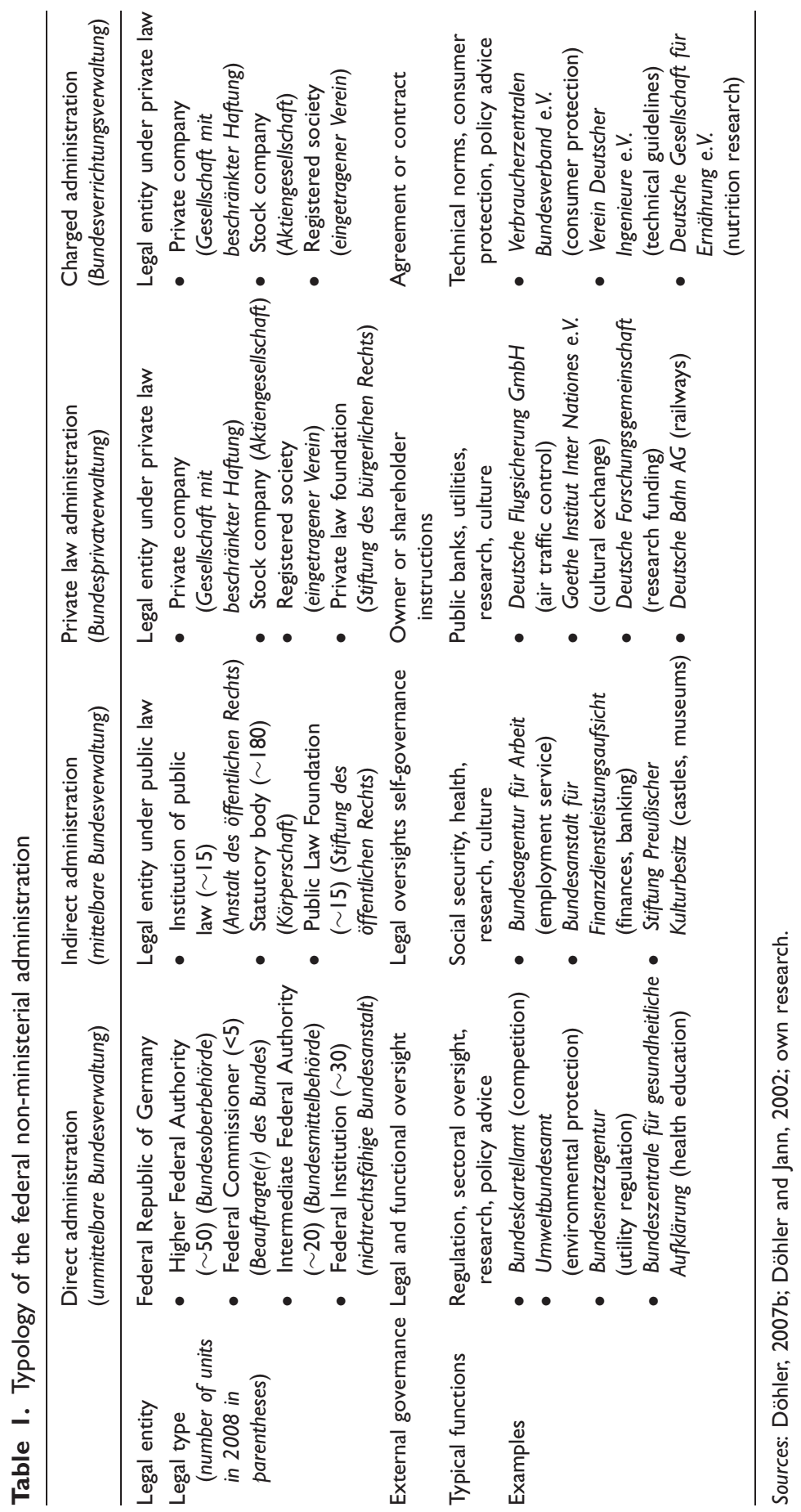


(Anstalten) typically administer policies such as promoting agriculture and film production, weather forecasting, real estate management, but also cultural policies such as international broadcasting and the national library. In most cases, also here societal actors are involved in the management of those organizations via governing or advisory boards (Loeser, 1994). (3) Finally, Foundations of Public Law (Stiftungen des öffentlichen Rechts) typically operate in the areas of culture and historical commemoration (e.g. the Prussian Cultural Heritage Foundation).

The distinction between direct and indirect administration is particularly important with regard to the ministries' right to issue directives and request information. In this context, administrative law distinguishes between legal oversight (Rechtsaufsicht) and functional oversight (Fachaufsicht). Legal oversight focuses on the subordinate organizations' conformity to generic laws and regulations (e.g. budget, public service), whereas functional oversight is much more comprehensive, covering all aspects of administrative operations, including the ministries' right to issue instructions on policy implementation and single decisions. The organizations belonging to the direct administration are - with very few exceptions subject to full ministerial oversight (i.e. both legal and functional oversight), while indirect administrative bodies are generally subject to legal, but not functional oversight because this would conflict with the principle of societal self-governance (Loeser, 1994).

The private law administration and the charged administration belong to the sphere of public enterprises and non-governmental bodies (Döhler, 2007a; Schuppert, 1981). The private law administration consists of organizations which are either totally or partially owned by the state. Here we find state-owned companies like the federal railways, but more typically scientific, cultural or developmental organizations are traditionally organized as private law organizations fully funded by the public sector (among others the Goethe Institut Inter Nationes which promotes the German language and culture abroad; the major research funding organization Deutsche Forschungsgemeinschaft; or the different organizations in developmental assistance). Finally, the charged administration consists of totally private organizations that carry out public tasks on behalf of the state, such as the German Nutrition Society (Deutsche Gesellschaft für Ernährung) which regularly publishes a nutrition report on behalf of the federal ministry in charge. In contrast to the direct and indirect administrations, the abovementioned types of ministerial oversight usually do not apply to private law and charged administrations, which are governed via owner or shareholder instructions and agreements or contracts, respectively. ${ }^{4}$

\section{Which 'animals' are 'agencies?}

Although all above-mentioned organizational types perform some type of public task, they have very different positions on a continuum of formal autonomy from politicians' influence (Döhler, 2007a; Greve et al., 1999; Loeser, 1994). Thus, the 
question remains whether all these organizations should be considered 'agencies'? According to a widely used definition by Pollitt et al. (2004: 10), an agency is characterized by a public law legal status, functional separation from the parent ministry, some decision-making competencies which are not enjoyed by the parent ministry itself (e.g. managerial decisions), but no full statutory independence from the parent ministry.

According to this definition, the private law and charged administrations do not qualify as agencies because of their private law status. Also, in this article, the large majority of statutory bodies will not be considered agencies because they do not operate under the direct supervision of a federal ministry (this task has been delegated to a Higher Federal Authority) and are self-governing bodies without state involvement. There are very few statutory bodies over which government has some direct control by means of functional oversight or participation in the governing board (e.g. the Federal Employment Agency or Bundesagentur für Arbeit). In sum, we consider the legal types within the direct administration and indirect administration (with the exception of most statutory bodies) to be agencies according to the above-mentioned definition. In the section on procedural agencification, we investigate whether direct and indirect agencies differ with regard to their practical autonomy and the relationships with their parent ministries.

Yet in contrast to standard assumptions about the well-ordered public sector in Germany, legal categories often remain ambiguous and flexible. In general, decision-makers enjoy rather large degrees of freedom with regard to institutional choice (the legal buzzword here is Formenwahlfreiheit, i.e. freedom to choose a legal type) (Benz and Goetz, 1996; Döhler, 2007b; Loeser, 1994). In many cases, it is not possible to deduce an agency's legal status from its name. Also, most organizations operating for the Ministry of Development Cooperation and the Foreign Office are private law bodies (except for the embassies) and may be considered to be 'agencies' in a functional sense. Thus, classifying agencies (or any other type of public organization or 'quango') by formal autonomy has potential drawbacks, as the agencies' 'practical autonomy' (Greve et al., 1999: 144), 'real autonomy' (Yesilkagit, 2004: 531) or 'actual level of autonomy' (Bouckaert and Peters, 2004: 24) may not correspond to their formal autonomy. It is obvious that tasks which for example in the UK have been delegated to agencies (e.g. pension funds) have in Germany never been ministerial functions at all, and are still today not even agencies in a formal sense. International comparisons should therefore start from tasks, not from legal forms or formal definitions of agencies.

\section{The norms and practices of ministry-agency relations in a legalistic system}

In terms of administrative norms and traditions, the principle of departmental sovereignty, the separation between policy and operations and the legalistic state tradition are extremely important for understanding the relationship between ministries and agencies in Germany. The principle of departmental sovereignty 
dominates decision-making within the federal executive and is jealously defended by politicians and the ministerial bureaucrats. This (constitutionally sanctioned) principle stipulates that each minister independently conducts the affairs of his or her portfolio within the general policy guidelines set by the chancellor and the cabinet's decisions. In addition to the minister's right to issue directives to agencies, the minister formally decides on agency organization, budgets, chief executive recruitment, the delegation of decision-making authority or specific tasks, the use performance contracting, or structural reforms (e.g. merging agencies). In empirical terms, this relative autonomy of ministries regarding the management of subordinate agencies leads to significant differences between ministries with regard to the norms and practices of (functional) oversight (Bundesrechnungshof, 2007; Döhler, 2007a).

The separation between policy and operations is at the core of the (implicit) ideal-type model of administration in Germany (Döhler, 2007b). According to the normative doctrine of 'legislative programming' of the administration, all important policy decisions have to be taken by parliament, and the bureaucracy can act only after empowerment through a specific law. As a result, agencies are considered to be administrative units outside the sphere of politics. The main purpose for setting up agencies (or delegating tasks to existing agencies) is to relieve ministries of so-called non-ministerial tasks, which allegedly do not require close political scrutiny (PRVR, 1975). Hence, although agency tasks may be highly politicized (e.g. financial market regulation, immigration, food safety), they are considered purely operational from a legal point of view. The delegation of tasks to agencies is not considered problematic from a democratic perspective, since the principles of legality and ministerial accountability ensure an unbroken chain of democratic legitimacy. This formal chain has been interrupted in only a few cases, such

as the Federal Court of Audit (Bundesrechnungshof) or the Federal Bank (Deutsche Bundesbank), whereas other agencies like the Federal Cartel Office (Bundeskartellamt) do not have de facto autonomy from ministerial oversight. In sum, there are very few independent agencies in the federal administration.

\section{Administrative reform policies}

In terms of public management reforms, the federal government is considered to be a 'maintainer' (Pollitt and Bouckert, 2004) and reform-laggard (Schröter, 2007). The main initiatives for modernizing the public sector started at the local level in the early 1990s and were only gradually adopted at the state and federal levels (Kuhlmann et al., 2008; Jann, 2004; Reichard, 2003). With the appointment of the 'lean state' reform commission in 1995, NPM-inspired reform concepts reached the federal level in 1995. However, the commission was rather hesitant to provide a comprehensive reform programme and suggested an incremental and decentralized reform approach (Sachverständigenrat 'Schlanker Staat', 1997). Among other things, it suggested introducing various management instruments (including target agreements), but the subsequent reform programme focused on 
streamlining administrative operations by reducing the number of agencies (Lenkungsausschuß Verwaltungsorganisation, 1998). Even though the federal government moved from Bonn to Berlin in the 1990s (which implied a massive reallocation of staff), it rejected all discussions about the future size and functions of ministries and agencies mainly for political reasons (protection of Bonn) (Jann and Wewer, 1998; Schröter, 2007). As a result, even today federal ministries are located in both cities and more than half of all employees of federal ministries still work in Bonn. ${ }^{5}$

The red-green government (1998-2005) pursued its administrative reform policy under the label of the 'activating state', thus offering a programmatic alternative to the cutback-oriented reform agenda of the previous government and emphasizing the importance of the state in supporting the problem-solving capacities of civil society (Jann, 2003). However, putting this reform policy to work proved to be rather difficult and most approaches of the preceding government found their way into the new reform programme, including efforts to reduce the number of federal authorities (Schröter, 2007). Also, similar to the previous government, the use of target agreements between ministries and agencies (and further down the administrative apparatus, e.g. with field offices) was included in the reform programme. Yet, due to the principle of departmental sovereignty, each ministry decides independently whether and how to implement this (and any other) management instrument.

The reform efforts of the red-green government were to a large extent continued incrementally by the grand coalition government (2005-09) under the heading of innovation and 'getting ready for the future' (BMI, 2006). With regard to agencies, in response to criticism by the Federal Audit Office, the federal ministries agreed on somewhat general principles of functional oversight, in which strategic planning and target agreements are explicitly mentioned as steering instruments, in addition to more traditional instruments such as directives (BMI, 2008).

In sum, there has been no overarching administrative policy aimed specifically at federal agencies and their relations with ministries across various functions of government, neither for modern agencies in the NPM tradition (as in the UK and the Netherlands; Greve et al., 1999) nor for independent regulatory agencies (as in Norway; Christensen and Lægreid, 2007). Administrative reforms focusing on agencies emphasized streamlining and reducing the number of authorities and a voluntary implementation of selected management instruments, and creating or changing agencies is driven primarily by perceived sectoral policy requirements. Each ministry deals with its own agencies in its own specific way. There is some political rhetoric mentioning the requirements of modern management and/or regulation, but no overall discussion or programme. In this article, we will move beyond official 'talk' and 'decisions' by assessing patterns of organizational change within the federal administration. 


\section{Data and methods}

The empirical data on structural and procedural agencification were collected through a comprehensive survey of all federal administrative organizations matching the definition of an agency presented earlier in this article. ${ }^{6}$ The total population is 122 organizations, and the response rate is 59.8 percent $(n=73){ }^{7}$ Organizations that are not directly supervised by a federal ministry (e.g. decentralized units), the military branch of the armed forces, the federal ministries and organizations with a similar legal status (e.g. the Federal Court of Audit, the Federal Bank) were not included in the survey. In addition, agencies which had been restructured shortly before the survey was distributed in spring 2008 were not included, namely the tax administration and the federal police. Also, we did not collect any survey data on the private law administration or the charged administration; hence the analysis concentrates on direct and indirect agencies, unless indicated otherwise.

The collection of perceptual data via an organizational survey has some inherent problems, such as respondent bias and differences in response rates between different types of organization (Yesilkagit and van Thiel, 2008). In terms of structural changes, respondents were asked to indicate the year in which the organization was created in its present legal form, and how this creation process took place (i.e. newly founded organization, successor of an existing organization, organizational merger or split-up). As a consequence, our data reflect the most recent structural change of the organizations, but no structural changes before the year of creation reported in the survey. Thus, the data provide a snapshot rather than a comprehensive overview of structural changes over longer periods of time. In order to track changes over longer periods of time, a comprehensive document analysis would be required, which is beyond the scope of this article (see Lægreid et al., 2010). Also, survey data could be biased by the respondents' perception regarding the type of organizational change. For instance, the creation of a new organization out of two existing organizations could be interpreted as a merger or the succession of an existing organization (e.g. if one of the organizations is much larger than the other). However, if such data were collected by the researchers themselves, problems of attributing types of change are likely to occur too. In sum, by triangulating our findings with qualitative data and secondary literature, we are able to draw pretty robust conclusions regarding structural changes within the federal administration during the past two decades.

As to procedural agencification, we analyse questions which ask for factual data (e.g. whether the agency has a target agreement with its parent ministry) and perceptual data (e.g. the agency's assessment of its autonomy along several dimensions vis-a-vis its parent ministry). Thus, the data generally reflect perceived levels of agency autonomy, as opposed to the formal and the actual level of agency autonomy (Bouckaert and Peters, 2004). Here, similar to the questions on structural changes, respondent bias may occur, caused by the characteristics of the person who completed the questionnaire. The questionnaire was addressed directly to the 
president or managing director of the agencies, who completed 45 percent of the questionnaires. Another 27 percent of the questionnaires were filled in by heads of division. Thus, we believe that the data provide a fairly reliable picture of senior management's perception of agency autonomy and how they are steered and controlled by their parent ministry.

\section{The structural dimension of agencification}

For the analysis of changes in organizational structures, we look at two dimensions of change. On the one hand, we distinguish between a horizontal and a vertical division of labour among administrative units (Bogumil and Jann, 2009; Lægreid et al., 2010). A horizontal division of tasks implies that organizational units at the same level of hierarchy perform different tasks. Here, a classical example is the division of labour between ministries, each having its characteristic task portfolio (e.g. finance, environment, labour, etc.). A vertical division of labour implies that organizational units at different hierarchical levels perform similar tasks, as in the case of ministerial departments and executive agencies (e.g. a ministry for consumer protection and a food safety agency). On the other hand, we distinguish between processes of specialization, in which the bureaucratic apparatus becomes more differentiated and fragmented, and processes of de-specialization, which imply a structural integration of formerly separate organizations. These analytical perspectives can be combined into four basic types of inter-organizational change (Table 2).

In the following, we look at patterns of organizational changes within the direct and indirect federal administration. We first analyse the survey data and then discuss our findings.

\section{Survey results}

Table 3 summarizes the results of the survey with regard to the sample population's year of creation, as indicated by the survey respondents. These findings indicate the number of structural changes per decade for direct and indirect administrative bodies.

Table 2. Four basic types of inter-organizational change

\begin{tabular}{llc}
\hline & Vertical division of labour & Horizontal division of labour \\
\hline Specialization & $\begin{array}{r}\text { Hiving-off tasks and personnel from } \\
\text { ministerial departments to agencies; } \\
\text { change into more autonomous legal type }\end{array}$ & $\begin{array}{c}\text { Splitting existing agencies into } \\
\text { single-purpose agencies }\end{array}$ \\
De-specialization & $\begin{array}{r}\text { (Re-)integration of agencies into ministries; } \\
\text { change into less autonomous legal type }\end{array}$ & Merging of existing agencies \\
\hline
\end{tabular}


The analysis focuses mainly on the past two decades, but we also contrast our findings for this period with long-term developments.

In general, the respondents report a lot of changes in the past two decades. Table 3 shows that 44 percent of the agencies in the sample have undergone some form of change since 1990. Also, there is a clear difference in the intensity of changes between direct and indirect administration. Almost 62 percent of the indirect agencies in the sample report changes between 1990 and 2008, whereas only about 37 percent of all direct agencies have been subject to changes during the same period.

In a longer time perspective, we find that until the end of the 1960s, most changes took place within the direct federal administration. Also, the data suggest a high stability especially of direct agencies: about 63 percent of the direct agencies in the survey were created before 1990, whereas only 38 percent of the indirect agencies were created in the same period. Clearly, the data should be treated carefully in terms of analysing long-term developments. However, other research supports the observed patterns of many changes among direct agencies in the 1950s and a substantial increase in structural changes in the 1990s and 2000s, especially among indirect agencies (Döhler, 2007a) ${ }^{8}$ But what kind of structural changes can be observed after 1990? To what extent can we observe a vertical specialization from ministries to agencies on the one hand, and from direct agencies to indirect agencies on the other hand?

With regard to the four basic types of inter-organizational changes (Table 2), the survey mainly provides information on horizontal specialization (splitting of agencies) and de-specialization (merger of agencies). In the survey, the category of succession includes processes of vertical de-specialization (e.g. hiving-off tasks

Table 3. Agency creation per period

\begin{tabular}{|c|c|c|c|c|c|c|c|c|c|}
\hline & & \multicolumn{8}{|c|}{ Before } \\
\hline & & 1949 & $1950-59$ & $1960-69$ & $1970-79$ & $1980-89$ & 1990-99 & $2000-08$ & Total \\
\hline \multirow{3}{*}{$\begin{array}{l}\text { Direct } \\
\text { adm. }\end{array}$} & row \% & 17.3 & 23.1 & 11.5 & 9.6 & 1.9 & 19.2 & 17.3 & 100.0 \\
\hline & column \% & 90.0 & 92.3 & 75.0 & 62.5 & 50.0 & 62.5 & 56.3 & 71.2 \\
\hline & $N$ & 9 & 12 & 6 & 5 & I & 10 & 9 & 52 \\
\hline \multirow{3}{*}{$\begin{array}{l}\text { Indirect } \\
\text { adm. }\end{array}$} & row $\%$ & 4.8 & 4.8 & 9.5 & 14.3 & 4.8 & 28.6 & 33.3 & 100.0 \\
\hline & column \% & 10.0 & 7.7 & 25.0 & 37.5 & 50.0 & 37.5 & 43.8 & 28.8 \\
\hline & $N$ & I & I & 2 & 3 & 1 & 6 & 7 & 21 \\
\hline \multirow[t]{2}{*}{ Total } & row \% & 13.7 & 17.8 & 11.0 & 11.0 & 2.7 & 21.9 & 21.9 & 100.0 \\
\hline & $N$ & 10 & 13 & 8 & 8 & 2 & 16 & 16 & 73 \\
\hline
\end{tabular}


Table 4. Types of structural change (direct and indirect agencies, 1990-2008)

\begin{tabular}{llccccc}
\hline & & Merger & Split-up & Succession & Founding & Total \\
\hline Direct adm. & row \% & 36.8 & 10.5 & 36.8 & 15.8 & 100.0 \\
& column \% & 77.8 & 100.0 & 50.0 & 42.9 & 59.4 \\
& $N$ & 7 & 2 & 7 & 3 & 19 \\
Indirect adm. & row \% & 15.4 & 0.0 & 53.8 & 30.8 & 100.0 \\
& column \% & 22.2 & 0.0 & 50.0 & 57.1 & 40.6 \\
& $N$ & 2 & 0 & 7 & 4 & 13 \\
Total & row \% & 28.1 & 6.3 & 43.8 & 21.9 & 100.0 \\
& $N$ & 9 & 2 & 14 & 7 & 32 \\
\hline
\end{tabular}

from a ministry to an agency), but it also includes changes of a legal type both within and across the direct and indirect administration. The fourth survey category covers newly created agencies (founding), which we consider as vertical specialization (a newly emerging task is delegated to an agency instead of keeping it in the ministry). ${ }^{9}$ The findings on different types of structural changes among direct and indirect agencies after 1990 are reported in Table 4.

The majority of structural changes among both direct and indirect agencies since 1990 were successions, i.e. changes in legal type. Indirect agencies have a disproportionately high share in structural changes by succession, followed by founding. In contrast, mergers and successions are most common among direct agencies. Direct agencies are therefore clearly overrepresented in structural changes via horizontal de-specialization. Finally, very few spin-offs (i.e. horizontal specialization) can be observed. Successions and mergers are the most common types of structural changes since 1990; whereas most structural changes before 1990 (both direct and indirect agencies) were creations (59 percent) and successions of existing organizations (32 percent) (not reported in the table).

The survey also provides evidence of a somewhat limited vertical specialization in terms of hiving-off tasks from ministries to agencies, whereas vertical specialization from the direct to the indirect administration is much more common. All respondents were asked to provide information on the predecessor organization of their agency, and many of them answered this question. Among the agencies created since 1990, only four originated in a ministry department (both direct and indirect agencies), with two agencies being created as the result of the privatization of the postal services and telecommunications (see below). In contrast, we find that six out of eight indirect agencies (75 percent, one missing answer) created since 1990 resulted from the succession or merger of direct agencies.

In sum, the survey findings suggest that structural changes in the federal administration since 1990 are mainly characterized by processes of horizontal de-specialization among direct agencies and vertical specialization from direct to indirect agencies. 
But federal agencies have neither taken over considerable functions from federal ministries, nor has there been a distinct development of single-purpose agencies. In the next section, we supplement the survey findings with qualitative analyses in order to complete the picture on structural agencification in the federal administration.

\section{Horizontal de-specialization and sectoral reforms}

The findings from the survey suggest that vertical specialization in the form of hiving-off tasks from ministries to agencies is rather unusual in the federal administration. The replacement of the Ministry for Post and Telecommunication by the Regulatory Agency for Telecommunications and Postal Services (Regulierungsbehörde für Telekommunikation und Post) in 1998 and the transfer of the task of energy regulation from the Ministry of Economic Affairs to this agency in 2005 which then changed its name to Federal Utilities Agency (Bundesnetzagentur) are rare exceptions. These processes of vertical specialization did not follow the logic of efficiency and effectiveness of public management reforms, but were reactions to the liberalization and privatization of the telecommunications sector, i.e. effects of the regulatory reform movement (Böllhoff, 2005; Döhler, 2007a). In general, devolution from ministries to agencies seems otherwise to be restricted to minor competencies and operational tasks (Lenkungsausschuß Verwaltungsorganisation, 1998). For instance, the federal government presently aims at creating 'shared service centres' at the agency level in order to perform internal administrative functions in a more efficient and effective way (BMI, 2006). Thus, except for particular sector-specific reforms, there is no empirical evidence for a substantial devolution of public functions from ministries to agencies (and neither for re-integration of agencies). It seems that the system of 'executive federalism' and the existence of an already large number of agencies protected the federal administration against this typical symptom of agency fever (Benz and Goetz, 1996).

In addition to structural changes, the relatively large number of successions indicates numerous changes in and between legal types. Here, the objectives of escaping from cumbersome administrative law and budget procedures, flexibility in hiring and firing staff, etc. have played a major role. The creation of the Federal Financial Supervisory Authority (Bundesanstalt für Finanzdienstleistungsaufsicht) is a case of 'emigration' from direct to indirect administration, although it still operates under the legal and functional oversight of the responsible ministry, and it makes binding regulatory decisions (BT-Drs 14/7033, a good example of how little legal form tells us about functions and autonomy). Another example is the formal privatization (corporatization) of air traffic control (Deutsche Flugsicherung $G m b H$ ). The original intention, to go further towards financial privatization, was stopped when the Federal President refused to sign the bill into law, emphasizing that the freedom to choose a legal type for public tasks is eventually limited by the constitution where vital public services are concerned. In general, our data 
regarding the vertical dimension of structural agencification confirm a trend that 'the species populating the German zoo of parapublic institutions have remained fairly unchanged, but the animals are becoming ever more numerous and stronger and they are increasingly found outside their traditional enclosures' (Benz and Goetz, 1996: 21).

When it comes to the horizontal dimension of structural changes, organizational mergers have clearly dominated the development of the federal administration in the past two decades. For instance, several agencies were merged within the domain of the Federal Ministry of Transport and Housing in the 1990s (for more examples, see Füchtner, 2002). In the second decade, the most far-reaching step was the amalgamation of three agencies responsible for overseeing financial services (banking, stock exchange, insurance) in 2002 into the Federal Financial Supervisory Authority, again following a discussion about regulatory reform. In 2008, the Ministry of Food, Agriculture, and Consumer Protection merged several of its research agencies.

In contrast, horizontal spin-offs are much less frequent. The most prominent examples of horizontal de-specialization resulted from crisis situations, such as the break-up of the Federal Health Institute (Bundesgesundheitsamt) into three separate agencies after the so-called HIV scandal in 1994. In 2002, the responsibilities in the field of food safety were split among the Federal Authority for Consumer Protection and Food Safety (Bundesamt für Verbraucherschutz und Lebensmittelsicherheit) and the Federal Institute for Risk Assessment (Bundesinstitut für Risikobewertung) as a result of the BSE crisis (Döhler, 2007b).

In addition to scandals and crises, the national adaptation of EU legislation on regulatory reform also leads to processes of horizontal specialization into single purpose organizations. The Federal Bureau of Aircraft Accident Investigation (Bundesstelle für Flugunfalluntersuchung) was separated from the Federal Aviation Authority (Luftfahrtbundesamt) in 1998 in order to implement an EU directive which required the setting-up of an independent organization for technical scrutiny of aircraft accidents (Füchtner, 2002). Also, the EU had an indirect effect on separating risk management and risk assessment in consumer protection and food safety, as this solution was considered to match best with the institutional structure of the future European Food Safety Authority (EFSA) (Döhler, 2007b).

In sum, we find that the federal administration has undergone a number of changes throughout the past two decades. Yet, neither vertical de-specialization ('hiving-off') nor the creation of single-purpose organizations plays any significant role. In line with the general trend towards a smaller public sector in Germany, most changes involve the merger of existing organizations or the succession of an existing organization with a new legal basis. These findings are supported by a study on organizational terminations within the direct administration using researcher-generated data, which show that the slow decline in total numbers of organizations since the end of the 1980s results from mergers and privatizations rather than 'organizational death' (Adam et al., 2008). In general, the organizational structure of ministries and agencies has mainly stayed the same during the 
past 20 years, and '[n]o flocks of new organizations were created' (Pollitt and Bouckaert, 2004: 95).

\section{The procedural dimension of agencification}

In this section, we first look at the internal dimension of procedural agencification, i.e. how agencies perceive public sector regulations and their parent ministry's role with regard to managerial autonomy, and their perceived bureaucratic discretion regarding the implementation of their core tasks. Then, we analyse ministry-agency relations (i.e. the external dimension of procedural agencification) in terms of formal legal oversight arrangements and the ministries' use of hierarchical directives, the use of target agreements, performance indicators, and processes of target formulation. In order to detect possible differences between direct and indirect agencies, we use ANOVA statistics and cross-tabulation (percentages are indicated in the text).

\section{Managerial autonomy, 'red tape', and bureaucratic discretion}

In public sector organizations, specific laws and regulations on financial and personnel management create 'red tape' which restricts managerial autonomy, especially in administrative systems dominated by the rule-of-law tradition, where these internal regulations tend to be particularly detailed and inflexible (but bureaucrats in such systems also seek pragmatic solutions, see Benz and Goetz, 1996). In addition to these general rules and regulations, parent ministries may also try to keep the agencies' managerial autonomy under control (e.g. by delegating rather limited managerial decision competencies to the agencies).

The majority of agencies in the survey report very high or high degrees of managerial constraint caused by budgetary law and public service regulations, and we do not find any statistically significant differences between direct and indirect agencies (see Table 5). Nevertheless, the data suggest a somewhat higher degree of perceived 'red tape' in terms of financial management among indirect agencies: 43 percent of the indirect agencies report very high constraints due to budgetary law against 24 percent of the direct agencies. This is a surprising finding, considering that indirect agencies perceive more autonomy in terms of specific financial management decisions than direct agencies (Bach, 2010). We draw the conclusion that the desired (financial) management autonomy of indirect agencies is higher compared to direct agencies. Indirect agencies strive for more actual autonomy, which they consider appropriate to their formal autonomy as defined by their legal status (and possibly their tasks which tend to be more 'hands-on' compared to direct agencies). Public sector organizations with extended formal autonomy in combination with a managerial organizational culture (relative to the ministerial bureaucracy) tend to develop 'expectations among the leadership and personnel of the agency about its (future) real autonomy' (Yesilkagit, 2004: 534). 
Table 5. Autonomy, 'red tape' and ministry-agency relations by legal category (ANOVA, $p<0.05)$

\begin{tabular}{|c|c|c|c|c|c|c|}
\hline Variables & Category & $N$ & Mean & SD & $F$ & Sign. \\
\hline \multirow{2}{*}{$\begin{array}{l}\text { Managerial limitations due } \\
\text { to budgetary law }\end{array}$} & direct adm. & 51 & 2.25 & 0.91 & \multirow[t]{2}{*}{$0.7 \mid 4$} & \multirow[t]{2}{*}{0.401} \\
\hline & indirect adm. & 21 & 2.05 & 1.02 & & \\
\hline \multirow{2}{*}{$\begin{array}{l}\text { Managerial limitations due to } \\
\text { civil service law and collective } \\
\text { agreements for employees }\end{array}$} & direct adm. & 51 & 2.14 & 1.02 & \multirow[t]{2}{*}{0.026} & \multirow[t]{2}{*}{0.873} \\
\hline & indirect adm. & 21 & 2.10 & 1.00 & & \\
\hline \multirow{2}{*}{$\begin{array}{l}\text { Managerial limitations due to } \\
\text { parent ministry }\end{array}$} & direct adm. & 50 & 2.90 & 1.02 & \multirow[t]{2}{*}{2.006} & \multirow[t]{2}{*}{0.161} \\
\hline & indirect adm. & 19 & 3.37 & 1.67 & & \\
\hline \multirow{2}{*}{$\begin{array}{l}\text { Frequency of hierarchical } \\
\text { interventions (use of functional } \\
\text { oversight) by parent ministry }\end{array}$} & direct adm. & 44 & 2.27 & 0.62 & \multirow[t]{2}{*}{1.387} & \multirow[t]{2}{*}{0.244} \\
\hline & indirect adm. & 10 & 2.00 & 0.82 & & \\
\hline \multirow{2}{*}{$\begin{array}{l}\text { Importance of indicators for } \\
\text { steering relationship between } \\
\text { ministry and agency }\end{array}$} & direct adm. & 26 & 3.08 & 1.06 & \multirow[t]{2}{*}{2.053} & \multirow[t]{2}{*}{0.160} \\
\hline & indirect adm. & 15 & 3.60 & 1.24 & & \\
\hline
\end{tabular}

Managerial limitations and importance of indicators for steering relationship: I = to a very great extent, $2=$ to a great extent, $3=$ partly, $4=$ to a small extent, $5=$ not at all; Frequency of hierarchical interventions: $\mathrm{I}=$ never, $2=$ seldom, $3=$ sometimes, $4=$ often, $5=$ very often.

In contrast to these instances of red tape, federal agencies perceive relatively moderate levels of managerial constraints caused by their parent ministries. This finding is supported by earlier research according to which ministries have increasingly delegated managerial decisions to agencies (Döhler, 2007a). Also, we find that indirect agencies perceive lower degrees of managerial limitations compared to direct agencies. Again, the above-mentioned divergence between perceived and desired autonomy may provide an explanation for this finding. Yet these differences are not statistically significant, which is a result of the high degree of variation among indirect agencies. This suggests that the ministries' steering practices towards indirect agencies are more heterogeneous in comparison to direct agencies.

In terms of bureaucratic discretion, about 50 percent of the respondents do not feel restricted or only to a small extent by their parent ministry when choosing their clients and instruments (less than 5 percent complain about direct ministerial meddling), and nearly 70 percent perform their day-to-day tasks without any or only small involvement by the ministry (the remaining 30 percent take these decisions after consulting the ministry or within explicit ministry guidelines). Also, indirect agencies perceive significantly higher degrees of implementation autonomy with regard to task performance compared to direct agencies. ${ }^{10}$

Overall, we find that federal agencies perceive substantial constraints with regard to administrative decisions (financial and human resources management), but rather high degrees of bureaucratic discretion, especially among indirect agencies. In other words, agencies generally are more autonomous regarding policy 
implementation (outputs) compared to administrative procedures (inputs and throughputs) (Bach, 2010; Welz, 1988). Also, these findings suggest that federal agencies do not enjoy the kind of managerial freedom that is commonly associated with an ideal-typical, modern agency.

\section{Ministries and agencies: hierarchy or performance management?}

According to the typology of the federal administration, federal ministries have a full-fledged right of instruction towards direct agencies (functional and legal oversight), while they may not instruct indirect agencies on policy and implementation matters (legal oversight). However, our findings on vertical specialization suggest an increasing hybridization of legal categories (see Döhler, 2007b, for a similar argument). In our sample, 52 (90) percent of the indirect (direct) agencies are subject to both functional and legal oversight.

Hierarchical instructions are the classical instrument by which federal ministries steer their subordinate agencies, yet earlier research shows that ministries are rather reluctant to use their right to issue directives (Döhler, 2007a; Welz, 1988). These findings are supported by our results (see Table 5). ${ }^{11}$ We find no statistically significant differences between the frequency of hierarchical interventions towards direct and indirect agencies (ANOVA). However, 90 percent of the indirect agencies report that hierarchical interventions by the parent ministry happen 'never' or 'seldom' in comparison to 68 percent of the direct agencies.

With regard to the use of performance contracts or target agreements between ministries and agencies, the survey reveals that the majority of federal agencies do not have a target agreement with their parent ministry (61 percent), whereas 17 percent have a target agreement without measurable targets, and 19 percent have a target agreement including measurable targets. ${ }^{12}$ Also, relatively more direct agencies have some kind of target agreement (40 percent) compared to indirect agencies (25 percent).

In contrast, the use of internal performance documents is more widespread among federal agencies: 38 percent of all agencies use internal performance documents (e.g. strategic plans) containing measurable targets, 25 percent use such documents without measurable targets, and 38 percent do not have such a document (or do not have any targets). Furthermore, the use of internal documents with measurable targets is somewhat more common among indirect agencies (42 percent) compared to direct agencies (36 percent).

Finally, we asked whether the agencies use performance indicators to measure results. About 60 percent of all agencies in our sample use performance indicators (there are no statistically significant differences between direct and indirect administration). However, none of these agencies report that indicators are very important for the steering relationship with the parent ministry, 32 percent of the agencies report that indicators are important or important in part, respectively, and 37 percent report that indicators are of little or no importance for the steering 
relationship (no statistically significant differences between direct and indirect agencies, see Table 5).

According to public documents, the number of direct agencies using target agreements has increased substantially. In 1998, 38 agencies had target agreements with their oversight authority (Bundesregierung, 2002). In 2005, the federal government reported that 203 out of 429 federal authorities (including 324 lower federal authorities which are not included in our analysis) had target agreements with their respective oversight authority (BT-Drs 15/5111), whereas 37 percent of the federal authorities used internal target agreements in 2005 (Schröter, 2007, referring to public documents).

These are quite impressive figures, yet our data suggest that the agencies' target agreements with parent ministries do not contain measurable targets, and that performance information plays at most a secondary role for the ministry's oversight activities. In the German administrative tradition and culture, questions of legality are still of much greater importance than problems of efficiency or effectiveness. The dominant view is that equipping authorities with a legal mandate is sufficient to ensure administrative performance, leaving little room for manoeuvre for either ministries or agencies (Döhler, 2007a). Thus, although several ministries have entered into contractual relations with their agencies, we conclude that performance-oriented steering is not (yet) an established instrument of ministerial oversight and has not replaced traditional hierarchical oversight mechanisms (Döhler, 2007a; Schröter, 2007).

All in all, federal agencies have not changed very much in terms of procedural agencification when it comes to their relationship with parent ministries. Yet the findings suggest that using internal performance documents is more widespread compared to target agreements with the ministries. Also, the majority of agencies use performance indicators, but these indicators seem to play a bigger role for internal management than for ministry-agency relations. Furthermore, we find only few differences between direct and indirect agencies with regard to their relationships with parent ministries, indicating highly varied oversight practices which are not connected to legal categories. The overall impression is a slightly increasing performance orientation among the agencies, yet it remains to be seen how and if this will substantially affect ministry-agency relations.

\section{Conclusion}

The creation and reform of government agencies is an international reform trend, and several countries have developed administrative policies on structural or procedural agencification. With the exception of an overall reform programme of administrative streamlining in the 1990s, no comparable cross-sectoral policy can be found in the German context (Jann et al., 2008; Pollitt and Bouckaert, 2004). Taking a closer look, this is hardly surprising, as Germany has always had a rather large number of various types of federal agencies and a strong division of labour 
between ministries and agencies. Also, the strong departmentalization of the federal bureaucracy encourages sector-oriented, disjointed reforms. However, there has been some reform activity at the federal level, which inter alia touched upon agencies and their relations with ministries. Against this background, we mapped the different legal categories of the federal administration and provided an empirical account of structural changes, agency autonomy and ministry-agency relations through the analytical lens of the agencification literature.

The structural changes in the federal bureaucracy during the past two decades are characterized by consolidation and vertical specialization from direct to indirect administration (or even private law bodies) and some cases of horizontal despecialization (merging), but no substantial 'hiving-off' from ministries to agencies. The existing repertoire of legal types provides policy-makers with a large number of organizational alternatives, which allows for the creation of hybrid legal types (Döhler, 2007b). This explains why policy-makers obviously perceived no need to create a new legal type ('executive agency').

In general, we observe that structural changes in Germany are mainly triggered by sectoral developments and policy changes, rather than cross-sectoral administrative reform policies. This 'sectoral bias' is related to the strongly guarded principle of departmental sovereignty, which makes cross-departmental administrative reforms almost impossible. At the same time, considering organizational reforms in policy areas such as utilities, drugs, food, financial regulation, or flight accidents, it seems that structural changes in Germany tend to follow the 'regulatory state' pattern rather than the 'Next Steps' model.

When it comes to procedural agencification, our findings show that the use of performance-based steering instruments between ministries and agencies has not been implemented on a large scale, whereas we observe more performance orientation regarding the agencies' internal management. The ideal-type NPM agency has not been a powerful model in Germany. In line with the dominating rule-of-law tradition, legality is the bureaucracy's most important source of legitimacy, whereas efficiency and performance play only a secondary role (Benz and Goetz, 1996; Schröter, 2007). However, we observe some changes towards a more regulatory model of government agencies. This change is problem driven and sectoral, but it is there nevertheless. The regulatory reform discourse is, at least in Germany, much more important than the managerial one.

Thus the status of agencies may be gradually changing, which has more to do with changes in the overall development in the understanding of statehood, from the traditional intervention state towards the enabling or regulatory state, than with the managerial reforms of the last 20 years. Döhler (2006) has argued that there is a development from a 'classical administration', concerned with conditional rules, hierarchies and ministerial responsibility via a 'modern administration', relying more on consultation, expertise and cooperation, towards a new model of 'regulatory administration', characterized by giving mandates to independent agencies to set standards of their own, and a more disaggregated 
administration which relies less on ministerial responsibility and more on expertise, autonomy, and negotiation which should lead to new forms of legitimacy - or that is at least what is hoped for.

Since our data provide only a 'snapshot' and no historical development, we cannot confirm these observations, and there is thus a lot of scope for future research. But in Germany we see both the insistence on legality and hierarchy and the reinforcement of autonomy in government agencies. This change is incremental and 'creeping', it is certainly not comprehensive and planned. It is much more evolutionary than revolutionary, but it is exactly this that makes it so much more difficult to map and to understand. It could be that German administration has changed more in recent years, and will continue to change, than has been acknowledged so far. But this, again, makes for interesting times for scholars of public administration.

\section{Notes}

1. We would like to thank the anonymous reviewers and the guest editors of this issue for their comments on an earlier version of this article.

2. The special role of the federal government becomes apparent when one looks at the distribution of public employees in Germany. Most public employees in the so-called direct administration (i.e. the core administration, a more detailed definition follows below) are employed at the state level (57 percent, or 1,929,000), about 36 percent are employed at the local level (about 1,220,000), while only about 7 percent, or roughly 232,000, are employed at the federal level (Statistisches Bundesamt, 2009; own calculations). The federal level also consists of about 184,000 professional soldiers and roughly 47,000 public employees working for the (formally privatized) German railways.

3. Christopher Hood (1986: 188) uses the image of 'a zoo containing many animals' for the world of quangos (quasi non-governmental organizations).

4. In terms of size, most federal public employees work within the indirect administration (about 53 percent of all federal staff or 277,000; a large majority being within the social security sector), whereas 44 percent $(232,000)$ work within the direct administration, and about 18,000 , or 3 percent, are employed by private law organizations with a public shareholder majority (Statistisches Bundesamt, 2009; own calculations).

5. According to the latest official figures (2004), there are about 10,000 staff positions in Bonn and 9000 in Berlin (BT-Drs 16/158), and there is no evidence of any major changes of this situation.

6. The survey is part of a joint initiative of scholars from several countries studying public organizations, the so-called COBRA-network (Comparative Public Organisation Data Base for Research and Analysis; see www.publicmanagement-cobra.org).

7. The response rates of the different organizational types are 58 percent for direct agencies and 66 percent for indirect agencies; hence direct agencies are slightly underrepresented in the dataset compared with the total population.

8. Döhler (2007a) collected data via document analysis on the creation of direct and indirect agencies between 1950 and 2005 (without federal institutions and intermediate federal authorities), but his analysis does not account for specific types of change. 
9. The questions and answer categories on structural changes can be found in the Appendix.

10. Mann-Whitney test, $p=0.04$.

11. Here, only agencies that are subject to functional oversight are included in the analysis.

12. Three percent of the respondents answered that the agency has a target agreement not including any targets.

\section{Appendix: Survey questions on structural changes}

- Date of creation: In which year was the organization created in its present legal form? (answer category: year)

- Type of creation: How was the organization created at this point in time? (answer categories: merger, split-up, succession, new foundation)

- Predecessor organization: Please name the predecessor organization(s) of your organization. (answer category: text answer)

\section{References}

Adam C, Bauer MW and Knill C (2008) Ausmaß und Ursachen von Organisationsabbau in der deutschen Verwaltung: Eine empirische Analyse der unmittelbaren Bundesverwaltung. Verwaltungsarchiv 99(2): 153-173.

Bach T (2010) Policy and management autonomy of federal agencies in Germany. In: Lægreid $\mathrm{P}$ and Verhoest K (eds) Governance of Public Sector Organizations - Proliferation, Autonomy and Performance. Basingstoke: Palgrave Macmillan (forthcoming).

Becker B (1978) Zentrale nichtministerielle Organisationseinheiten der unmittelbaren Bundesverwaltung. Verwaltungsarchiv 69: 149-202.

Benz A and Goetz KH (1996) The German public sector: National priorities and the International Reform Agenda. In: Benz A and Goetz KH (eds) A New German Public Sector? Reform, Adaption and Stability. Aldershot, Brookfield, Singapore and Sydney: Dartmouth, 1-26.

BMI (2006) Zukunftsorientierte Verwaltung durch Innovationen. Berlin: Bundesministerium des Innern.

BMI (2008) Grundsätze zur Ausübung der Fachaufsicht der Bundesministerien über den Geschäftsbereich. Berlin: Bundesministerium des Innern.

Bogumil J and Jann W (2009) Verwaltung und Verwaltungswissenschaft in Deutschland. Wiesbaden: VS Verlag.

Böllhoff D (2005) The Regulatory Capacity of Agencies - A Comparative Study of Telecom Regulatory Agencies in Britain and Germany. Berlin: Berliner Wissenschafts-Verlag.

Bouckaert G and Peters BG (2004) What is available and what is missing in the study of quangos? In: Pollitt C and Talbot C (eds) Unbundled Government: A Critical Analysis of the Global Trend to Agencies, Quangos and Contractualisation. London and New York: Routledge, 22-49.

Brecht A and Glaser C (1940) The Art and Technique of Administration in German Ministries. Westport, CT: Greenwood Press, [reprint, 1970].

BT-Drs 14/7033 (2001) Entwurf eines Gesetzes über die integrierte Finanzdienstleistungsaufsicht. 
BT-Drs 15/5111 (2005) Moderne Managementmethoden für eine moderne Verwaltung. Antwort der Bundesregierung vom 16.03.2005 auf die Große Anfrage der Abgeordneten Dr. Volker Wissing, Otto Fricke, Jürgen Koppelin, weiterer Abgeordneter und der Fraktion der FDP.

BT-Drs 16/158 (2005) Antwort des Parlamentarischen Staatssekretärs Achim Großmann auf die schriftliche Frage des Abgeordneten Dr. Norbert Röttgen (CDU/CSU) vom 25. November 2005.

Bundesrechnungshof (2007) Bemerkungen 2007 zur Wirtschafts- und Haushaltsführung des Bundes.

Bundesregierung (2002) Moderner Staat - Moderne Verwaltung. Bilanz 2002. Berlin: Bundesministerium des Innern.

Caulfield JL (2004) Measuring autonomy in social security agencies: A four country comparison. Public Administration and Development 24(2): 137-145.

Christensen T and Lægreid P (2001) A transformative perspective on administrative reforms. In: Christensen $\mathrm{T}$ and Lægreid $\mathrm{P}$ (eds) New Public Management: The Transformation of Ideas and Practice. Aldershot, Burlington, Singapore and Sydney: Ashgate, 13-39.

Christensen T and Lægreid P (2007) Regulatory agencies - The challenge of balancing agency autonomy and political control. Governance 20(3): 497-519.

Dittmann A (1983) Die Bundesverwaltung: Verfassungsgeschichtliche Grundlagen, grundgesetzliche Vorgaben und Staatspraxis ihrer Organisation. Tübingen: Mohr.

Döhler M (2006) Regulative Politik und die Transformation der klassischen Verwaltung. In: Bogumil J, Jann W and Nullmeier F (eds) Politik und Verwaltung. Wiesbaden: VS Verlag, 208-227.

Döhler M (2007a) Die politische Steuerung der Verwaltung. Baden-Baden: Nomos.

Döhler M (2007b) Vom Amt zur Agentur? Organisationsvielfalt, Anpassungsdruck und institutionelle Wandlungsprozesse im deutschen Verwaltungsmodell. In: Jann W and Döhler M (eds) Agencies in Westeuropa. Wiesbaden: VS Verlag, 12-47.

Döhler M and Jann W (2002) Germany. In: OECD (ed.) Distributed Public Governance: Agencies, Authorities and other Autonomous Bodies. Paris: OECD, 97-112.

Füchtner N (2002) Die Modernisierung der Zentralverwaltung in Großbritannien und Deutschland: Strategien konservativer und sozialdemokratischer Regierungen. Frankfurt am Main: Peter Lang.

Gains F (2004) Adapting the agency concept: Variations within "Next Steps". In: Pollitt $\mathrm{C}$ and Talbot C (eds) Unbundled Government: A Critical Analysis of the Global Trend to Agencies, Quangos and Contractualisation. London and New York: Routledge, 53-74.

Greve C, Flinders M and Van Thiel S (1999) Quangos - What's in a name? Defining quangos from a comparative perspective. Governance 12(2): 129-146.

Hood C (1986) The hidden public sector: The "quangocratization" of the world? In: Kaufmann F-X, Majone F and Ostrom V (eds) Guidance, Control, and Evaluation in the Public Sector. Berlin and New York: de Gruyter, 183-207.

Jann W (2003) State, administration and governance in Germany: Competing traditions and dominant narratives. Public Administration 81(1): 95-118.

Jann W (2004) Verwaltungsmodernisierung auf der Bundesebene. In: Jann W, Bogumil J, Bouckaert G, et al. (eds) Status-Report Verwaltungsreform. Eine Zwischenbilanz nach zehn Jahren. Berlin: Edition Sigma, 100-111. 
Jann W and Reichard C (2003) Evaluating best practice in central government modernization. In: Wollmann H (ed.) Evaluation in Public Sector Reform. Cheltenham: Edward Elgar, 36-55.

Jann W and Wewer G (1998) Helmut Kohl und der "schlanke Staat". Eine verwaltungspolitische Bilanz. In: Wewer G (ed.) Bilanz der Ära Kohl. Christlich-liberale Politik in Deutschland 1982-1998. Opladen: Leske + Budrich, 229-266.

Jann W, Bach T, Fleischer J and Hustedt T (2008) Best Practice in Governance of Agencies A Comparative Study in View of Identifying Best Practice for Governing Agencies Carrying Out Activities on Behalf of the European Union. Brussels: European Parliament.

Kuhlmann S, Bogumil J and Grohs S (2008) Evaluating administrative modernization in German local governments: Success or failure of the "New Steering Model". Public Administration Review 68(5): 851-863.

Lægreid P, Roness PG and Rubecksen K (2006) Autonomy and control in the Norwegian civil service: Does agency form matter? In: Christensen T and Lægreid P (eds) Autonomy and Regulation: Coping with Agencies in the Modern State. Cheltenham: Edward Elgar, 235-267.

Lægreid P, Roness PG, Rolland VV and Ågotnes J-E (2010) The structural anatomy of the Norwegian state 1985-2007: Increased specialization or a pendulum shift? In: Lægreid P and Verhoest K (eds) Governance of Public Sector Organizations - Proliferation, Autonomy and Performance. Basingstoke: Palgrave Macmillan (forthcoming).

Lenkungsausschuß erwaltungsorganisation (1998) 'Schlanker Staat': Bilanz und Ausblick: Mehr Effektivität und Wirtschaftlichkeit der Bundesverwaltung. Bonn: Bundesministerium des Innern, Arbeitsgruppe Verwaltungsmodernisierung.

Loeser R (1994) System des Verwaltungsrechts, Bd. 2, Verwaltungsorganisationsrecht. BadenBaden: Nomos.

OECD (2002) Distributed Public Governance: Agencies, Authorities and other Government Bodies. Paris: OECD.

Pollitt C and Bouckaert G (2004) Public Management Reform: A Comparative Analysis, 2nd edn. Oxford: Oxford University Press.

Pollitt C, Bathgate K, Caulfield J, Smullen A and Talbot C (2001) Agency fever? Analysis of an international policy fashion. Journal of Comparative Policy Analysis 3(3): 271-290.

Pollitt C, Talbot C, Caulfield J and Smullen A (2004) Agencies: How Governments do Things through Semi-autonomous Organizations. London: Palgrave Macmillan.

PRVR (1975) Die nichtministerielle Bundesverwaltung. Erster Teil: Analyse. Bonn: Bundesministerium des Innern.

Reichard C (2003) Local public management reforms in Germany. Public Administration 81(2): 345-364.

Sachverständigenrat 'Schlanker Staat' (1997) Abschlussbericht, Band 1. Bonn: Sachverständigenrat 'Schlanker Staat' im Bundesministerium des Innern.

Schröter E (2007) Reforming the machinery of government: The case of the German federal bureaucracy. In: Koch R and Dixon J (eds) Public Governance and Leadership. Wiesbaden: Deutscher Universitäts-Verlag, 251-271.

Schuppert GF (1981) Die Erfüllung öffentlicher Aufgaben durch verselbständigte Verwaltungseinheiten: eine verwaltungswissenschaftliche Untersuchung. Göttingen: Schwartz.

Statistisches undesamt (2009) Finanzen und Steuern. Personal des öffentlichen Dienstes. Fachserie 14, Reihe 6. Wiesbaden: Statistisches Bundesamt. 
Talbot C (2004) The agency idea. In: Pollitt C and Talbot C (eds) Unbundled Government: A Critical Analysis of the Global Trend to Agencies, Quangos and Contractualisation. London and New York: Routledge, 3-21.

Verhoest K, Peters BG, Bouckaert G and Verschuere B (2004) The study of organisational autonomy: A conceptual review. Public Administration and Development 24(2): 101-118.

Welz W (1988) Ressortverantwortung im Leistungsstaat: Zur Organisation, Koordination und Kontrolle der selbständigen Bundesoberbehörden unter besonderer Berücksichtigung des Bundesamtes für Wirtschaft. Baden-Baden: Nomos.

Yesilkagit K (2004) Bureaucratic autonomy, organizational culture, and habituation: Politicians and independent administrative bodies in the Netherlands. Administration \& Society 36(5): 528-552.

Yesilkagit K and van Thiel S (2008) Political influence and bureaucratic autonomy. Public Organization Review 8(2): 137-153.

Tobias Bach is research fellow at the University of Hannover, Department of Political Science, Germany.

Werner Jann is Professor at the University of Potsdam, Faculty of Economics and Social Sciences, where he holds the chair of Political Science, Administration and Organization. 